ISSN 1392-3196 / e-ISSN 2335-8947

Zemdirbyste-Agriculture, vol. 104, No. 1 (2017), p. 41-46

DOI 10.13080/z-a.2017.104.006

\title{
Quantification of biologically active compounds in the tubers of potato varieties of different maturity
}

\author{
Vaiva BRAZINSKIENE ${ }^{1}$, Rita ASAKAVICIUTE ${ }^{1}$, Almantas RAZUKAS ${ }^{1}$, \\ Liudas IVANAUSKAS ${ }^{2}$ \\ ${ }^{1}$ Vokè Branch, Lithuanian Research Centre for Agriculture and Forestry \\ Žalioji 2, Traku Voké, Vilnius, Lithuania \\ E-mail: rita.asakaviciute@voke.lzi.lt \\ ${ }^{2}$ Lithuanian University of Health Sciences \\ A. Mickevičiaus 9, Kaunas, Lithuania
}

\begin{abstract}
High-performance liquid chromatography (HPLC) was used to identify and quantify fifteen amino acids and phenolic active compounds in the tubers of twelve potato (Solanum tuberosum L.) varieties: very early - 'VB Venta', 'Fresco', 'Acapella', early - 'Sante', 'Goda', 'VB Liepa', medium - 'Lady Rosetta', 'Red Lady', 'Courage' and late - 'VB Rasa', 'VB Aista', 'Saturna', grown in Lithuania. Investigation of the influence of the maturity time of different potato varieties on the accumulation of the tested compounds suggested that very early potato varieties accumulated higher levels of biologically active compounds than the other varieties tested. The tubers of all varieties tested accumulated the highest concentrations of tyrosine, tryptophan, chlorogenic and caffeic acids were mostly accumulated by all tested varieties.
\end{abstract}

Key words: high-performance liquid chromatography (HPLC), phenolic compounds, Solanum tuberosum.

\section{Introduction}

Potatoes are able to easily adapt to different growing conditions, produce high yields, are of high nutritional value, so they are very widespread and considered as the most important non-grain agricultural plant in the world (Brazinskiene, Gaivelyte, 2016). According to the data from United Nations Food and Agriculture Organization (FAO, 2011), potatoes are the fourth-most-consumed food crop in the world after rice, wheat and corn. Potatoes cause interest not only as nutritive crop; their health improving properties are being studied widely (Mahmoud, El-Anany, 2014). Potato tubers are beneficial for human health as they accumulate vitamins, minerals and significant quantities of phenolic compounds. After investigations on the contribution of phenolic compounds of 34 fruit and vegetable species in the American diet, Chun et al. (2005) revealed that potatoes are the third source of phenolic compounds in a daily diet after apples and oranges. Phenolic compounds, ascorbic acid and carotenoids are the main antioxidants accumulated in potatoes.

Potatoes cause interest not solely as nutritive crop; their health improving properties are being studied widely: protective effect of potato peel extract against oxidative damage in erythrocytes (Singh, Rajini, 2008), effect reducing the radiation induced conditions (Kanatt et al., 2005; Kaspar et al., 2011), inhibitory effect of potato extract on the proliferation of breast cancer (Leo et al., 2008), colon and liver cancer (Wang et al., 2011). Most of these positive effects are attributed to specific compounds or their combinations; therefore, in order to understand mechanisms that make potato a healthful plant, detailed knowledge of pharmacologically active compounds and their quantities accumulated in this plant is essential.

A wide variety of compounds are recorded in potato tubers: anthocyanins, carotenoids, glycoalcaloids, phenolic compounds, amino acids, etc. (TomoskoziFarkas et al., 2014; El-Kosasy et al., 2015; Seal, 2016). The main phenolic acids present in potato tubers are derivatives of hydroxycinnamic acid and hydroxybenzoic acid (Brazinskiene et al., 2014). Derivative of hydroxycinnamic acid - chlorogenic acid and its isomers - account for up to $90 \%$ or more of the total content of phenolic compounds found in potato tubers; additionally small amounts of caffeic, ferulic and coumaric acids are found (Ramamurthy et al., 1992; Friedman, Jurgens, 2000; Mattila, Hellström, 2007; Im et al., 2008; ElKosasy et al., 2015). Small quantities of hydroxybenzoic acid derivatives protocatechuic (3,4-dihydroxybenzoic acid), gallic, cinnamic and vanillic acids have been found in potatoes (Lewis et al., 1998; Mattila, Hellström, 2007; Mader et al., 2009). Small amounts of flavonoids: naringenin, eriodictyol, catechin, epicatechin (Lewis et al., 1998), as well as rutin (André et al., 2009) were also recorded in potato tubers. 
The current study was aimed to analyze the biologically active compounds of potato (Solanum tuberosum L.) grown in Lithuania.

\section{Materials and methods}

Plant material. Potatoes were grown in 20112012 at Vokè Branch of Lithuanian Research Centre for Agriculture and Forestry. Tubers of twelve potato (Solanum tuberosum L.) varieties differing in maturity were tested: very early - 'VB Venta', 'Fresco', 'Acapella', early - 'Santa', 'Goda', 'VB Liepa', medium - 'Lady Rosetta', 'Red Lady', 'Courage' and late - 'Saturna', 'VB Rasa', 'VB Aista'. Plants were grown in a sandy loam soil on carbonated fluvioglacial eluviated gravel (JDp) Haplic Luvisol (LVh), with pH 5.1-5.5, content of available phosphorus $\left(\mathrm{P}_{2} \mathrm{O}_{5}\right)-129-145 \mathrm{mg} \mathrm{kg}^{-1}$ of soil, potassium $\left(\mathrm{K}_{2} \mathrm{O}\right)-217-270 \mathrm{mg} \mathrm{kg}^{-1}$ of soil and organic carbon $(\mathrm{C})-0.79-0.84 \%$.

Conventional farming conditions. In the autumn, the field was sprayed with a herbicide Kernel 480 SL 31 ha $^{-1}$ (a.i. glyphosate $480 \mathrm{~g} \mathrm{l}^{-1}$ ). Then the soil was deeply ploughed. In the spring, the field was cultivated twice, and then the soil was cultivated with a rotary cultivator to a depth of $0.25 \mathrm{~m}$. The field was furrowed before the potato planting; potatoes were planted by hand. Potatoes were fertilized with a universal complex fertilizer Kemira Cropcare $\mathrm{N}_{10} \mathrm{P}_{10} \mathrm{~K}_{20}$, at planting time $80 \mathrm{~kg} \mathrm{ha}^{-1}$ of nitrogen $(\mathrm{N}), 80 \mathrm{~kg} \mathrm{ha}^{-1}$ of $\mathrm{P}_{2} \mathrm{O}_{5}$ and $160 \mathrm{~kg} \mathrm{ha}^{-1}$ of $\mathrm{K}_{2} \mathrm{O}$. After planting, the interrows were hilled up twice using a rotary hiller. When potatoes grew up to $10 \mathrm{~cm}$, the field was sprayed with a herbicide mixture Titus $50 \mathrm{~g} \mathrm{ha}^{-1}$ (a.i. rimsulfuron $250 \mathrm{~g} \mathrm{~kg}^{-1}$ ) with Mistral $500 \mathrm{~g} \mathrm{ha}^{-1}$ (a.i. metribuzin $700 \mathrm{~g} \mathrm{~kg}^{-1}$ ). After that the potatoes were twice earthed up. At inflorescence formation and flowering period, the plants were sprayed with a fungicide Acrobat Plus $2 \mathrm{~kg} \mathrm{ha}^{-1}$ (a.i. dimethomorph $90 \mathrm{~g} \mathrm{~kg}^{-1}$ and mancozeb $\left.600 \mathrm{~g} \mathrm{~kg}^{-1}\right)$ in combination with an insecticide Proteus OD $0.71 \mathrm{ha}^{-1}$ (a.i. thiacloprid $100 \mathrm{~g} \mathrm{l}^{-1}$ and deltamethrin $10 \mathrm{~g} \mathrm{l}^{-1}$ ). After two weeks, a fungicide Ridomil Gold $2.5 \mathrm{~kg} \mathrm{ha}^{-1}$ (a.i. metalaxyl-M $40 \mathrm{~g} \mathrm{~kg}^{-1}$ and mancozeb $640 \mathrm{~g} \mathrm{~kg}^{-1}$ ) in combination with an insecticide Proteus OD $0.71 \mathrm{ha}^{-1}$ were used. Two weeks before the harvest, the potato field was sprayed with the fungicide Shirlan 500 SC 0.41 ha $^{-1}$ (a.i. fluazinam $500 \mathrm{~g} \mathrm{l}^{-1}$ ).

Chemicals. Standards of fifteen compounds were used in the chromatographic analysis: chlorogenic acid, (-)-epicatechin, DL-catechin, gallic acid, eriodictyol (ChromaDex, USA), caffeic acid (Labor dr. Ehrenstrofer-Schafers, Germany), rutin trihydrate (HWI Analytik GmbH, Germany), vanillic acid, naringenin, trans-cinnamic acid, trans-p-coumaric acid, trans-ferulic acid, L-tryptophan, L-tyrosine and 3,4-dihydroxybenzoic acid (Sigma-Aldrich Production $\mathrm{GmbH}$, Switzerland).

Extraction. Five randomly chosen tubers were selected from the storage of each potato variety. Washed, air-dried and sliced potato tubers with skin were dried in a liophilisator (Ilshin Lab Co. Ltd., South Korea). Liophilised potatoes were ground in a knife mill Grindomix GM 200 (Retsch, Germany) to the powder. When preparing an analytical sample, $1 \mathrm{~g}$ of the obtained powder was placed into analytical flask and poured over with acetic acid, methanol and water (5:147:98) mixture to $10 \mathrm{ml}$ and placed into an ultrasonic cleaner Biosonic UC100 (Coltene/Whaledent Inc., USA) for 20 minutes.
Later the obtained potato extract was filtered, first through paper and then through the membrane filter with $0.22 \mu \mathrm{m}$ pore size. The prepared extract was chromatographed. For each extract sample three extracts were prepared for testing.

High-performance liquid chromatography (HPLC) analysis. The analysis was carried out using a chromatograph Waters 2695 (Waters, USA). For separation of active compounds $4.6 \times 250 \mathrm{~mm}, 5 \mu \mathrm{m}$ ACE C18 column (Advanced Chromatographic Technologies, Scotland) was used, during the analysis it was kept at an external Waters temperature control module, maintaining $25^{\circ} \mathrm{C}$ temperature. During the analysis, $10 \mu \mathrm{m}$ of the test solution were injected. The mobile phase flow rate was $1 \mathrm{ml} \mathrm{min}{ }^{-1}$. The following gradient system was used: solvent $\mathrm{A}-0.5 \%$ acetic acid in water, solvent $\mathrm{B}$ - methanol; $0 \mathrm{~min}-95 \% \mathrm{~A}$ and $5 \% \mathrm{~B}, 40 \mathrm{~min}-40 \% \mathrm{~A}$ and $60 \% \mathrm{~B}, 41 \mathrm{~min}-10 \% \mathrm{~A}$ and $90 \% \mathrm{~B}, 55 \mathrm{~min}-10 \%$ $\mathrm{A}$ and $90 \% \mathrm{~B}, 56 \mathrm{~min}-95 \% \mathrm{~A}$ and $5 \% \mathrm{~B}$. The separated active compounds were analyzed using photodiode array detector Waters 996 PDA (Waters, USA) at a wavelength ensuring their maximum absorption: chlorogenic acid $325 \mathrm{~nm}$, epicatechin $-277 \mathrm{~nm}$, catechin $-277 \mathrm{~nm}$, gallic acid $-269 \mathrm{~nm}$, eriodictyol - 286, caffeic acid $-323 \mathrm{~nm}$, rutin $-254 \mathrm{~nm}$, vanillic acid - $258 \mathrm{~nm}$, naringenin $288 \mathrm{~nm}$, cinnamic acid $-275 \mathrm{~nm}$, coumaric acid $-309 \mathrm{~nm}$, ferulic acid - $322 \mathrm{~nm}$, tryptophan $-277 \mathrm{~nm}$, tyrosine $273 \mathrm{~nm}, 3,4$-dihydroxybenzoic acid $-257 \mathrm{~nm}$. The data were collected and analyzed using a chromatographic manager system Waters Millennium 2000 (Waters, USA). Statistical analysis. One way ANOVA and correlation-regression analyses were performed using the software SigmaStat 3.5 (2005).

\section{Results and discussion}

When HPLC is used in search for separation systems suitable for determination of active compounds accumulated in potato tubers, gradient elution, with water and methanol or acetonitrile as mobile phase is most commonly used (Lewis et al., 1998; Mattila, Hellström, 2007; Soloft et al., 2010). This research data indicate that the best results were achieved when $0.5 \%$ acetic acid solution in water (A) and methanol (B) were used for gradient elution. The best resolution formed using $4.6 \times 250 \mathrm{~mm}, 5 \mu \mathrm{m}$ ACE C18 column. In total, fifteen compounds were separated with the following retention times: $6.2 \mathrm{~min}$ - tyrosine, $7.9 \mathrm{~min}$ - gallic acid, $13.0 \mathrm{~min}$ - 3,4-dihydroxybenzoic acid, $15.9 \mathrm{~min}$ - tryptophan, $17.3 \mathrm{~min}$ - catechin, $18.8 \mathrm{~min}$ - chlorogenic acid, $21.1 \mathrm{~min}$ - vanillic acid, $21.7 \mathrm{~min}$ - caffeic acid, $22.5 \mathrm{~min}$ - epicatechin, $27.2 \mathrm{~min}$ - coumaric acid, $28.4 \mathrm{~min}-$ ferulic acid, $32.8 \mathrm{~min}$ - rutin, $37.0 \mathrm{~min}$ - eriodictyol, $40.2 \mathrm{~min}$ - cinnamic acid, $41.1 \mathrm{~min}$ - naringenin. All peaks were completely separated (resolution $>1.5$ ) (Fig. 1). The separated active compounds were analyzed at a wavelength ensuring their maximum absorption. The method specificity was checked according to two parameters: retention time of the tested compound peak and photodiode array (PDA) spectrum matching the standard.

Method validation parameters were chosen according to The International Conference on Harmonisation Guidelines (Guideline ICH, 1997). Validation results are presented in Table. Calibration 


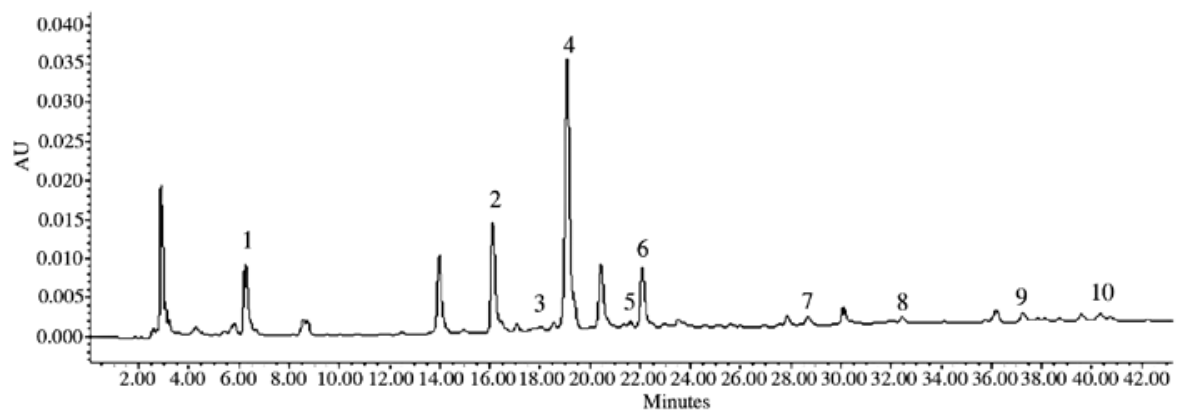

AU - absorbance, minutes - retention time; 1 - tyrosine, 2 - tryptophan, 3 - catechin, 4 - chlorogenic acid, 5 - vanillic acid, 6 - caffeic acid, 7 - ferulic acid, 8 - rutin, 9 - eriodictyol, 10 - cinnamic acid

Figure 1. High-performance liquid chromatography (HPLC) chromatogram of potato variety 'Saturna' at $275 \mathrm{~nm}$ wavelength

Table. Calibration curves and other parameters of separated compounds and within-day and between-day precision of assay for determination of analyzed compounds in standard solution

\begin{tabular}{|c|c|c|c|c|c|c|c|}
\hline \multirow{2}{*}{ Analyte } & \multirow{2}{*}{$\begin{array}{c}\text { Fixed linear } \\
\text { range } \\
\mu \mathrm{g} \mathrm{ml}^{-1}\end{array}$} & \multirow{2}{*}{ Equation } & \multirow{2}{*}{$r^{2}$} & \multirow{2}{*}{$\begin{array}{c}\text { LOD } \\
\mu \mathrm{g} \mathrm{ml}^{-1}\end{array}$} & \multirow{2}{*}{$\begin{array}{c}\text { LOQ } \\
\mu \mathrm{g} \mathrm{ml}^{-1}\end{array}$} & \multicolumn{2}{|c|}{ RSD $\%$ for amount } \\
\hline & & & & & & WD & $\mathrm{BD}$ \\
\hline Tyrosine & $0.83-13.25$ & $\mathrm{Y}=4.37 \times 10^{4} \mathrm{X}-4.46 \times 10^{2}$ & 0.9991 & 0.572 & 1.906 & 1.83 & 1.54 \\
\hline Gallic acid & $0.20-12.80$ & $\mathrm{Y}=3.23 \times 10^{4} \mathrm{X}-2.31 \times 10^{3}$ & 0.9998 & 0.119 & 0.395 & 0.57 & 0.65 \\
\hline 3,4-dihydroxybenzoic acid & $0.42-26.59$ & $\mathrm{Y}=3.76 \times 10^{4} \mathrm{X}-1.86 \times 10^{3}$ & 0.9998 & 0.051 & 0.170 & 0.13 & 0.52 \\
\hline Tryptophan & $0.42-26.56$ & $\mathrm{Y}=1.65 \times 10^{4} \mathrm{X}-7.79 \times 10^{2}$ & 0.9998 & 0.131 & 0.437 & 0.48 & 0.70 \\
\hline Catechin & $0.21-13.16$ & $\mathrm{Y}=6.35 \times 10^{3} \mathrm{X}-2.66 \times 10^{2}$ & 0.9997 & 0.385 & 1.284 & 0.57 & 1.13 \\
\hline Chlorogenic acid & $0.13-12.69$ & $\mathrm{Y}=3.06 \times 10^{4} \mathrm{X}-5.88 \times 10^{3}$ & 0.9990 & 0.062 & 0.208 & 0.32 & 1.69 \\
\hline Vanillic acid & $0.41-26.13$ & $\mathrm{Y}=3.77 \times 10^{4} \mathrm{X}-2.64 \times 10^{3}$ & 0.9998 & 0.052 & 0.174 & 0.21 & 0.64 \\
\hline Caffeic acid & $0.40-25.73$ & $\mathrm{Y}=5.65 \times 10^{4} \mathrm{X}-1.56 \times 10^{4}$ & 0.9996 & 0.051 & 0.171 & 0.17 & 1.20 \\
\hline Epicatechin & $0.20-13.04$ & $\mathrm{Y}=7.26 \times 10^{4} \mathrm{X}+1.04 \times 10^{3}$ & 0.9994 & 0.206 & 0.687 & 0.92 & 0.83 \\
\hline Coumaric acid & $0.41-26.45$ & $\mathrm{Y}=7.92 \times 10^{4} \mathrm{X}-2.05 \times 10^{4}$ & 0.9998 & 0.058 & 0.195 & 0.17 & 1.08 \\
\hline Ferulic acid & $0.41-26.51$ & $\mathrm{Y}=5.52 \times 10^{4} \mathrm{X}-3.37 \times 10^{4}$ & 0.9990 & 0.054 & 0.181 & 0.44 & 2.57 \\
\hline Rutin & $0.20-12.84$ & $\mathrm{Y}=1.56 \times 10^{4} \mathrm{X}+5.73 \times 10^{1}$ & 0.9998 & 0.197 & 0.658 & 0.63 & 0.86 \\
\hline Eriodictyol & $0.19-12.37$ & $\mathrm{Y}=4.10 \times 10^{4} \mathrm{X}-1.02 \times 10^{3}$ & 0.9998 & 0.058 & 0.192 & 0.55 & 0.63 \\
\hline Cinnamic acid & $0.42-26.64$ & $\mathrm{Y}=8.33 \times 10^{4} \mathrm{X}-1.56 \times 10^{3}$ & 0.9999 & 0.020 & 0.067 & 0.18 & 0.54 \\
\hline Naringenin & $0.34-26.41$ & $\mathrm{Y}=3.78 \times 10^{4} \mathrm{X}+1.99 \times 10^{3}$ & 0.9990 & 0.049 & 0.162 & 0.25 & 0.91 \\
\hline
\end{tabular}

$r^{2}$ - coefficient of determination, LOD - limit of detection, LOQ - limit of quantification, RSD - relative standard deviation, WD within-day precision (repeatability), BD - between-day precision (intermediate precision); $\mathrm{Y}$ - peak area, $\mathrm{X}$ - amount

curves reflecting linearity of detector response were obtained by the analysis of six different overlay levels of standard mix solutions, each injected three times. The obtained determination coefficients are close to 1, so it indicates very good detector response linearity in the tested range of overlay levels. The lower limits for application of quantification method were determined by the signal (s) - noise (n) ratio method: $s / n=3$ for detection limit (LOD) and $\mathrm{s} / \mathrm{n}=10$ for quantification limit (LOQ).

The method precision was determined by withinday and between-day re-examination of the standard mix of the average concentration. Parameters of method precision (repeatability and intermediate precision) were calculated from three series of samples with six injections each and expressed as relative standard deviation (RSD\%), presented in Table $1 . \mathrm{RSD} \%$ of within-day and between-day did not exceed $3 \%$, which is a good result, corresponding to the requirements for validation of quantitative research in pharmaceutical products. The method accuracy was evaluated by triplicate injections of each of three different concentrations of standards mix: maximum, medium and minimum (Fig. 2). Difference between mean and accepted true value varied from $-3.81 \%$ to $2.97 \%$.

The developed method was used for the analysis of potato tubers of twelve Lithuania-grown varieties. The results show that the highest amount of active compounds was accumulated in var. 'VB Venta' tubers - 2078.00 \pm $73.99 \mu \mathrm{g} \mathrm{g}^{-1}$, while the lowest amount was accumulated in var. 'Lady Rosetta' tubers $-555.79 \pm 7.00 \mu \mathrm{g} \mathrm{g}^{-1}$ (Fig. 3).

The tested potato varieties represent different maturity groups (very early, early, medium and late). It was found that very early potato varieties accumulated higher levels of biologically active compounds than the other tested varieties. Between accumulated total amounts of active compounds in early, medium and late potato varieties there was found no statistically significant difference (Fig. 4). 


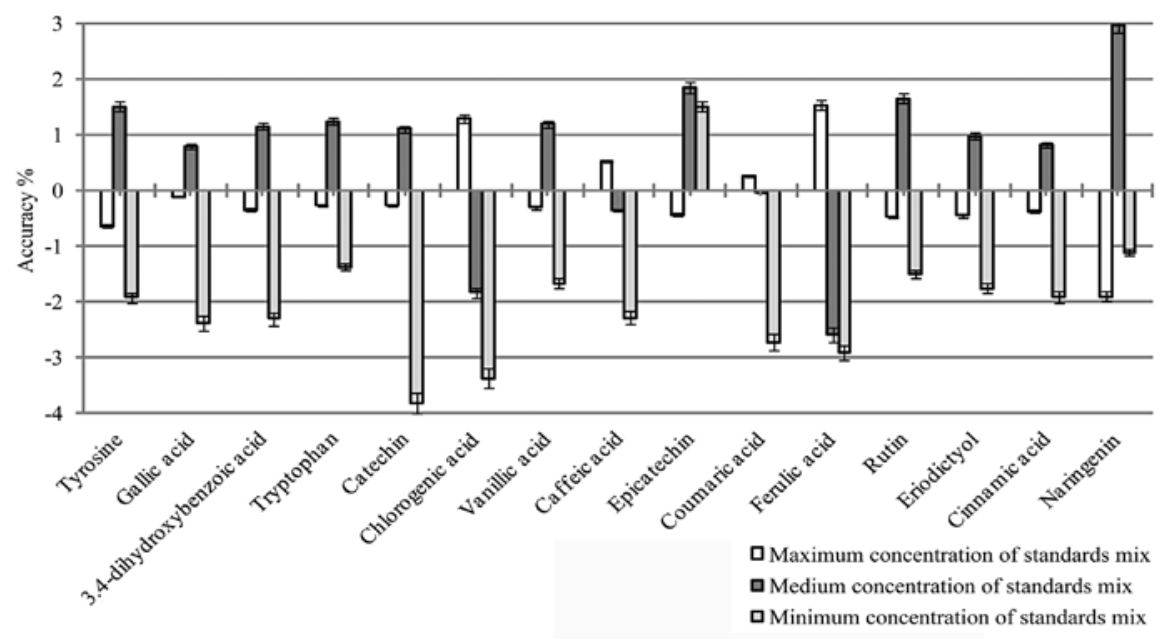

Figure 2. Accuracy of analytical method, reported as difference between mean and accepted true value

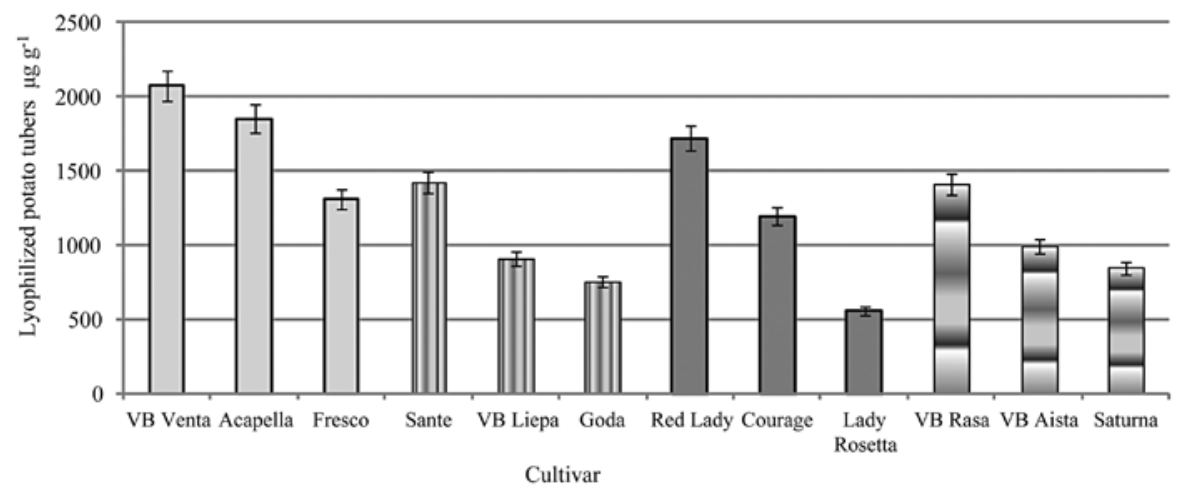

Figure 3. Total amounts of accumulated biologically active compounds in potato tubers of different maturity

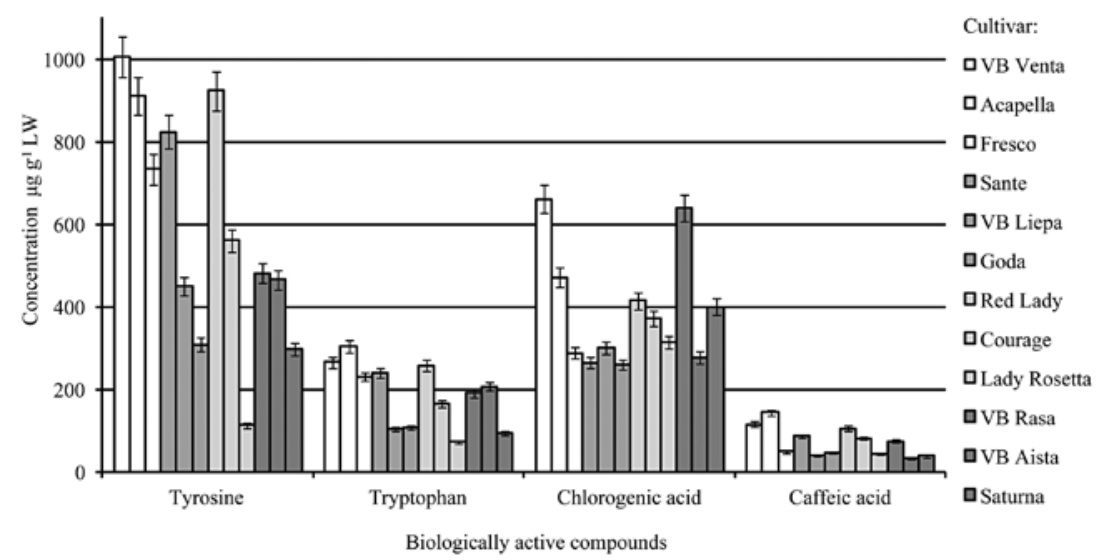

LW - lyophilized potato tubers; mean of triplicated analysis (values are means of three replicates \pm standard error of the mean)

Figure 4. Amounts of active compounds accumulated in tubers of different potato varieties

None of the analyzed potato varieties contained gallic acid, protocatechuic acid and naringenin. Small amounts of epicatechin were recorded only in var. 'Goda' $\left(6.88 \pm 0.58 \mu \mathrm{g} \mathrm{g}^{-1}\right)$ and catechin only in var. 'VB Venta' $\left(2.74 \pm 0.44 \mu \mathrm{g} \mathrm{g}^{-1}\right)$, slight amounts of coumaric acid were recorded in varieties 'Courage' $\left(2.55 \pm 0.55 \mu \mathrm{g} \mathrm{g}^{-1}\right)$ and 'Goda' $\left(3.99 \pm 0.05 \mu \mathrm{g} \mathrm{g}^{-1}\right)$, while eriodictyol - in var. 'Saturna' $\left(2.20 \pm 0.31 \mu \mathrm{g} \mathrm{g}^{-1}\right)$. All other compounds were detected in all the tested varieties, except for rutin which was not detected in varieties 'Courage', 'Sante' and 'Fresco'. Chlorogenic acid and caffeic acid were the major phenolic acids in tubers of all the tested varieties. According to other researchers, the amount of chlorogenic acid in potato tubers ranges from 11 to $637 \mu \mathrm{g} \mathrm{g}^{-1}$, depending on the variety (Ramamurthy et al., 1992; André et al., 2009). In Lithuania, chlorogenic acid depending on the potato variety comprises from $72 \%$ to $87 \%$ and caffeic acid - from $8 \%$ to $23 \%$ of the total content of phenolic compounds. Contents of other phenolic acids were less than $40 \mu \mathrm{g} \mathrm{g}^{-1}$.

Tubers of all the tested varieties contained considerable amounts of tyrosine and tryptophan. Strong 
positive correlation $\left(r^{2}=0.83\right)$ was observed between the amounts of these two amino acids. The highest amount of tyrosine was detected in var. 'VB Venta' tubers, and of tryptophan - in var. 'Acapella' tubers. The least amount of these amino acids was accumulated in var. 'Lady Rosetta' tubers.

The analysis of potato tubers showed that all the tested varieties accumulated the highest amounts of tyrosine, tryptophan, chlorogenic and caffeic acids (Spagnol et al., 2015). Trace amounts of other tested phenolic compounds were detected, except for gallic and protocatechuic acids and naringenin, which were not detected. These results confirm the statement that chlorogenic acid is the major phenolic acid in potato tubers.

\section{Conclusions}

1. High-performance liquid chromatography (HPLC) method enabling quantitative evaluation of fifteen phenolic compounds in potato tubers was adapted and validated.

2. Investigated potato varieties belong to different maturity groups: very early - 'VB Venta', 'Fresco', 'Acapella', early - 'Sante', 'Goda', 'VB Liepa', medium - 'Lady Rosetta', 'Red Lady', 'Courage' and late - 'VB Rasa', 'VB Aista', 'Saturna'. Statistically significant difference $(p<0.01)$ between the total amount of active compounds accumulated in the potato varieties belonging to different maturity group was found. Very early potato varieties accumulated higher levels of biologically active compounds than the other tested varieties. No statistically significant difference was found between the accumulated total amount of active compounds in early, medium and late potato varieties.

3. The quantification of fifteen phenolic compounds detected in Lithuania-grown potato tubers showed chlorogenic acid to be dominant among them. The detected amount of chlorogenic acid comprises from $72 \%$ to $87 \%$ and caffeic acid from $8 \%$ to $23 \%$ of the total content of phenolic compounds. Contents of other phenolic acids were less than $40 \mu \mathrm{g} \mathrm{g}^{-1}$.

\section{Acknowledgements}

Research results were obtained through a long-term research program "Genetics and purposeful change of genotypes of agricultural and forest plants" implemented by Lithuanian Research Centre for Agriculture and Forestry.

Received 03062016

Accepted 13012017

\section{References}

André C. M., Oufir M., Hoffmann L., Hausman J.-F., Rogez H., Larondelle Y., Evers D. 2009. Influence of environment and genotype on polyphenol compounds and in vitro antioxidant capacity of native Andean potatoes (Solanum tuberosum L.). Journal of Food Composition and Analysis, 22: $517-524$

https://doi.org/10.1016/j.jfca.2008.11.010

Brazinskiene V., Gaivelyte K. 2016. Organic potatoes. Advances in potato chemistry and technology, p. 315-337 https://doi.org/10.1016/b978-0-12-800002-1.00011-x
Brazinskiene V., Asakaviciute R., MiezelieneA.,Alencikiene G., Ivanauskas L., Jakstas V., Viskelis P., Razukas A. 2014. Effect of farming systems on the yield, quality parametrs and sensory properties of conventionally and organically grown potato (Solanum tuberosum L.) tubers. Food Chemistry, 145: 903-909 https://doi.org/10.1016/j.foodchem.2013.09.011

Chun O. K., Kim D. O., Smith N., Schroeder D., Han J. T., Lee C. Y. 2005. Daily consumption of phenolics and total antioxidant capacity from fruit and vegetables in the American diet. Journal of the Science of Foodand Agriculture, 85 (10): 1715-1724 https://doi.org/10.1002/jsfa.2176

El-Kosasy A. M., Hussin L. A., Ayad M. F., Fares N. V. 2015. Optimization of extraction, HPLC and einetic etudies for determination of some food tainting compounds in different food matrices. Journal of Chromatographic Science, 53 (9): 1504-1519 https://doi.org/10.1093/chromsci/bmv046

FAO. 2011. FAO Statistical Databases <http://www.fao.org/ faostat/en/\#home>

Friedman M., Jurgens H. 2000. Effect of pH on the stability of plant phenolic compounds. Journal of Agricultural and Food Chemistry, 40: 2101-2110 https://doi.org/10.1021/jf990489j

Guideline ICH. 1997. Harmonized Tripartite. Q2B validation of analytical procedures: methodology, $13 \mathrm{p}$.

Im H. W., Suh B.-S., Lee S.-U., Kozukue N., OhnisiKameyama M., Levin C. E., Friedman M. 2008. Analysis of phenolic compounds by high-performance liquid chromatography and liquid chromatography/ mass spectrometry in potato plant flowers, leaves, stems, and tubers and in home-processed potatoes. Journal of Agricultural and Food Chemistry, 56: 3341-3349 https://doi.org/10.1021/jf073476b

Kanatt S. R., Chander R., Radhakrishna P., Sharma A. 2005. Potato peel extract - a natural antioxidant for retarding lipid peroxidation in radiation processed lamb meat. Journal of Agricultural and Food Chemistry, 53: 1499-1504 https://doi.org/10.1021/jf048270e

Kaspar K. L., Park J. S., Brown C. R., Mathison B. D., Navarre D. A., Chew B. P. 2011. Pigmented potato consumption alters oxidative stress and inflammatory damage in men. The Journal of Nutrition, 141: 208-211 https://doi.org/10.3945/jn.110.128074

Leo L., Leone A., Longo C., Lombardi D. A., Raimo F., Zacheo G. 2008. Antioxidant compounds and antioxidant activity in "early potatoes". Journal of Agricultural and Food Chemistry, 56: 4154-4163 https://doi.org/10.1021/jf073322w

Lewis C. E., Walker J. R. L., Lancaster J. E., Sutton K. E. 1998. Determination of anthocyanins, flavonoids and phenolic acids in potatoes. I: Coloured cultivars of Solanum tuberosum L. Journal of the Science of Food and Agriculture, 77:45-57 https://doi.org/10.1002/(SICI)10970010(199805)77:1<45::AID-JSFA1>3.0.CO;2-S

Mader J., Rawel H., Kroh L. W. 2009. Composition of phenolic compounds and glycoalkaloids $\alpha$-solanine and $\alpha$-chaconine during commercial potato processing. Journal of Agricultural and Food Chemistry, 57 (14): 6292-6297 https://doi.org/10.1021/jf901066k

Mahmoud A. H., El-Anany A. M. 2014. Nutritional and sensory evaluation of a complementary food formulated from rice, faba beans, sweet potato flour, and peanut oil. Food and Nutrition Bulletin, 35: 403-413 https://doi.org/10.1177/156482651403500402

Mattila P., Hellström J. 2007. Phenolic acids in potatoes, vegetables, and some of their products. Journal of Food Composition and Analysis, 20: 152-160 https://doi.org/10.1016/j.jfca.2006.05.007 
Ramamurthy M. S., Maiti B., Thomas P., Nair P. M. 1992. High-performance liquid chromatography determination of phenolic acids in potato tubers (Solanum tuberosum) during wound healing. Journal of Agricultural and Food Chemistry, 40: 569-572 https://doi.org/10.1021/jf00016a007

Seal T. 2016. Quantitative HPLC analysis of phenolic acids, flavonoids and ascorbic acid in four different solvent extracts of two wild edible leaves, Sonchus arvensis and Oenanthe linearis of North-Eastern region in India. Journal of Applied Pharmaceutical Science, 6 (2): 157-166 https://doi.org/10.7324/JAPS.2016.60225

Singh N., Rajini P. S. 2008. Antioxidant-mediated protective effect of potato peel extract in erythrocytes against oxidative damage. Chemico-Biological Interactions, 173: 97-104 https://doi.org/10.1016/j.cbi.2008.03.008

Soloft M., Nielsen J., Laursen K. H., Husted S., Halekoh U., Knuthsen P. 2010. Effects of organic and conventional growth systems on the content of flavonoids in onions and phenolic acids in carrots and potatoes. Journal of Agricultural and Food Chemistry, 58: 10323-10329 https://doi.org/10.1021/jf101091c

Spagnol C. M., Isaac V. L. B., Corrêa M. A., Salgado H. R. N. 2015. Validation of HPLC-UV assay of caffeic acid in emulsions. Journal of Applied Pharmaceutical Science, 54: 305-311

https://doi.org/10.1093/chromsci/bmv142

Tomoskozi-Farkas R., Berki M., Nagy-Gasztonyi M., Wolf I., Polgar Zs. 2014. Investigation of antinutritive components in Hungarian potato cultivars depending on production technology. Acta Alimentaria, 43 (1): 188-196 https://doi.org/10.1556/AAlim.43.2014.Suppl.26

Wang Q., Chen Q., He M., Mir P., Su J., Yang Q. 2011. Inhibitory effect of antioxidant extracts from various potatoes on the proliferation of human colon and liver cancer cells. Nutrition and Cancer, 63: 1044-1052 https://doi.org/10.1080/01635581.2011.597538

ISSN 1392-3196 / e-ISSN 2335-8947

Zemdirbyste-Agriculture, vol. 104, No. 1 (2017), p. 41-46

DOI 10.13080/z-a.2017.104.006

\title{
Biologiškai aktyvių junginių kiekis skirtingo ankstyvumo veislių bulvių gumbuose
}

\author{
V. Bražinskienè ${ }^{1}$, R. Asakavičiūtè ${ }^{1}$, A. Ražukas ${ }^{1}$, L. Ivanauskas² \\ ${ }^{1}$ Lietuvos agrarinių ir miškų mokslų centro Vokès filialas \\ ${ }^{2}$ Lietuvos sveikatos mokslų universitetas
}

\section{Santrauka}

Siekiant bulvių gumbuose identifikuoti ir kiekybiškai nustatyti penkiolika amino rūgščių bei fenolinių aktyvių junginių, taikytas didelio slègio skysčio chromatografijos metodas. Šių junginių kiekiai tirti Lietuvoje užaugintų dvylikos veislių bulvių gumbuose: labai ankstyvų - 'VB Venta', 'Fresco', 'Acapella', ankstyvu - 'Sante', 'Goda', 'VB Liepa', vidutinio ankstyvumo - 'Lady Rosetta', 'Red Lady', 'Courage' ir vėlyvu - 'VB Rasa', 'VB Aista', 'Saturna'. Vertinant gumbų subrendimo laiko įtaką tirtų junginių kiekiui nustatyta, kad labai ankstyvų bulvių gumbai sukaupé daugiau biologiškai aktyvių junginių nei kitų tirtų veislių bulvių. Atlikto tyrimo duomenimis, visų veislių bulvių gumbuose daugiausia buvo sukaupta tirozino, triptofano, chlorogeno ir kavos rūgščių.

Reikšminiai žodžiai: fenoliniai junginiai, skysčio chromatografija, Solanum tuberosum. 